\title{
Sposoby spędzania czasu wolnego przez kobiety skazane na karę pozbawienia wolności jako potencjał do rozumienia znaczenia readaptacji społecznej
}

\author{
Ways of Spending Free Time by the Women Sentencend \\ To Imprisonment as a Potential for Understanding the \\ Meaning of Social Rehabilitation
}

Streszczenie. Celem tekstu jest próba pokazania sposobów zagospodarowania czasu wolnego w warunkach izolacji przez dorosłe kobiety jako rezultat przeprowadzonych otwartych pogłębionych wywiadów ze skazanymi w wybranych instytucjach resocjalizacyjnych. Tutaj nadmiar czasu staje się głównym problemem, ale też możliwością prowadzenia działań edukacyjnych i to nie tylko naprawczych, ale także rozwijających. Staram się pokazać trud zagospodarowania własnego pola aktywności przez skazane w warunkach przymusu, ale w tym samym działaniu widzę wysiłek ukierunkowany na stawanie się odpowiedzialnym dorosłym.

Postępowanie badawcze przyjęło charakter analizy znaczenia treści wypowiedzi badanych w taki sposób, aby doprowadzić do utworzenia jednorodnych tematycznie kondensacji sensu. Wyróżniono następujące kategorie oddające znaczenie czasu wolnego w wypowiedziach skazanych kobiet:

(A) Praca jako podstawowy wymiar opisu czasu wolnego;

(B) Uczenie się i uzupełnianie edukacji jako formy spędzania czasu wolnego;

(C) Zajęcia kulturalno-oświatowe jako sposób spędzania wolnego czasu;

(D) Gry jako forma spędzania wolnego czasu;

(E) Sport jako aktywność pożądana i rezultat potrzeby rywalizacji;

(F) Czas wolny jako czas na kontakt z rodziną.

Słowa kluczowe: czas wolny, kobiety, resocjalizacja, edukacja.

Summary. The purpose of the text is an attempt to present the ways of organizing the free time activities in isolation by adult women. The results were achieved by using the open depth interviews with convicts in prisons. 
The excess of free time becomes a major problem, but it is also the opportunity for educational activities, not only correctional but also developing new competences. I am trying to show the difficulties with arranging of own area activities under duress by the prisoners. In the same activity I see an effort directed to becoming an responsible adult.

The research proceedings took a character of the analysis of the meanings of the interview content of the respondents in such a way to create thematically homogenous condensation sense.

The following types reflecting the meaning of the free time were distinguished:

A) Work as a elementary descriptive dimension of the free time.

B) Learning and completing the education as a form of spending the free time;

C) Cultural - educational activities as a form of spending the free time;

D) Games as a form of spending the free time;

E) Sports activity as desirable and necessary result of competition;

F) Free time as the time to contact family.

Keywords: free time, women, social rehabilitation, education.

\section{Czas wolny - wprowadzenie w problematykę badań}

Różnorodność definicji czasu wolnego już na początku planowania procedury badawczej w pewnym stopniu komplikuje przedsięwzięcie badawcze, później sprawia trudności interpretacyjne. Najczęściej objawia się to w postaci niepewności co do umieszczenia interpretowanego materiału badawczego i sposobu odniesienia się do niego.

Spośród wielu określeń czasu wolnego w podjętych badaniach przyjąłem definicję za Krzysztofem Przecławskim, który określa czas wolny jako ten, który pozostaje człowiekowi do jego swobodnej dyspozycji po wykonaniu czynności związanych z zaspokojeniem potrzeb biologicznych i higienicznych oraz czynności obowiązkowych (Przecławski, 1997). Jan Pięta (2004) uważa czas wolny za wolny od uciążliwych zobowiązań i traktuje go jako stan umysłu. Definicja ta ma pewne słabości, gdyż to, co dla jednych jest brakiem zobowiązań i aktywnością samą dla siebie, dla innych może być uciążliwe.

Czas wolny może mieć inne znaczenie dla osób w różnych życiowych sytuacjach. W kontekście izolacji więziennej pojęcie czasu wolnego można rozumieć jako czas przeznaczony do swobodnej dyspozycji skazanej po wypełnieniu przez nią obowiązków wynikających z faktu pozostawania w jednostce penitencjarnej. 
Niektóre kobiety przebywające w warunkach izolacji więziennej mogą stawać przed problemem zagospodarowania czasu wolnego, co może stanowić źródło kolejnych trudności. Osoby skazane pozostające w izolacji więziennej należą do kategorii osób, które mogą doświadczać przymusowo czasu wolnego. Czas ten może być odpowiednio wykorzystany albo utracony. Dla niektórych skazanych czas wolny może być źródłem nowych doświadczeń edukacyjnych, a dla innych bezwartościowym, a nawet demoralizującym czynnikiem w ich rozwoju. Fakt, że skazane mają niewiele obowiązków i w związku z tym dysponują dużą ilością czasu wolnego, nie oznacza, że w sposób swobodny mogą dokonywać wyborów w zakresie jego spędzania. Wybory te zależą m.in. od regulaminu zakładu karnego czy specyfiki jednostki penitencjarnej.

W literaturze przedmiotu najczęściej pojawiają się cztery podstawowe funkcje czasu wolnego: rekreacja fizyczna i psychiczna, zabawa, samorozwój, funkcja uspołeczniająca (Grochociński, 1980).

Pierwsza funkcja polega na odpoczynku, który łagodzi zmęczenie i sprawia dobre fizyczne lub psychiczne samopoczucie. Jego pogorszenie może wynikać z napięć spowodowanych w szczególności, choć nie wyłącznie, przez wykonywanie swojej pracy i innych obowiązków, a w przypadku osadzonych kobiet $\mathrm{z}$ samego faktu izolacji.

Druga funkcja służy rozrywce, co pozwala na poradzenie sobie z nudą wynikającą $z$ monotonii i powtarzalności codziennych zajęć. W jednostce penitencjarnej mamy do czynienia ze zjawiskiem standaryzacji, które z jednej strony zapewnia skazanym pewną przewidywalność i postępowanie według określonych norm, a z drugiej strony uprzedmiotawia ich poprzez traktowanie wszystkich skazanych jako osoby posiadające te same potrzeby oraz w ten sam sposób zaspokajane. W efekcie może dochodzić do uczucia znudzenia u skazanych i związanej z nim frustracji.

Trzecia funkcja dotyczy rozwoju osobowości poprzez uwolnienie od rutynowych zachowań i stereotypów wynikających z automatyzacji i specjalizacji w wykonywaniu codziennych czynności. W zakładzie karnym obserwujemy szereg rutynowych aktywności, w których uczestniczą skazane kobiety. Działania te przede wszystkim wynikają z regulaminu zakładu karnego oraz kodeksu karnego wykonawczego.

Ostatnia, czwarta funkcja - uspołeczniająca - realizowana jest prawie zawsze wtedy, gdy formy spędzania czasu wolnego wykorzystują interakcje zachodzące $w$ grupie lub służą późniejszym działaniom społecznym. Interakcje społeczne na terenie zakładu karnego posiadają pewną specyfikę wy- 
nikającą chociażby ze społecznej struktury samych skazanych tworzących podgrupy oraz relacji między personelem a skazanymi kobietami.

Pojęcie czasu wolnego jest związane z zagadnieniem wolności. Czas wolny zazwyczaj jest kwestią indywidualnego wyboru. Natomiast formy spędzania go przez skazane kobiety są ograniczone warunkami, w jakich pozostają. Nie mają one swobodnej możliwości decydowania o formach spędzania wolnego czasu. Skazane nie dysponują pełną autonomią i wyborem ze względu na to, iż większość aspektów codziennego życia w jednostce penitencjarnej jest ustalona odgórnie.

Nadmiar czasu wolnego wśród skazanych sprzyja ich wzajemnej demoralizacji, a także stanowi zagrożenie dla osób pozostających na terenie jednostki penitencjarnej. W związku z powyższym należy uznać, że istnieje szereg powodów, dla których konieczna jest odpowiednia organizacja czasu wolnego osób skazanych na karę pozbawienia wolności.

\section{Uwagi metodologiczne dotyczące realizacji projektu}

Zgodnie z prezentowanymi statystykami Centralnego Zarządu Służby Więziennej w ostatnich latach obserwujemy wzrost liczby kobiet osadzanych w zakładach karnych*. W pierwszym kwartale 2001 r. w jednostkach penitencjarnych pozostawało 1991 kobiet, natomiast w 2014 r. znajdowało się 2746 skazanych. W celach mają one zazwyczaj niewiele przestrzeni, lecz dużo czasu wolnego. $Z$ perspektywy pedagogiki resocjalizacyjnej istotnym jest na ile sposoby spędzania czasu wolnego przez skazane służą ich readaptacji społecznej po opuszczeniu zakładu karnego. Czas wolny w warunkach izolacji więziennej może rodzić specyficzne problemy społeczne i badawcze. Biorąc pod uwagę ilość czasu wolnego kobiet pozostających w zakładzie karnym, pojawiają się pytania:

W jaki sposób kobiety osadzone w zakładach karnych spędzają czas wolny?

Jakie znaczenie mają poszczególne formy spędzania czasu wolnego dla osadzonych kobiet?

Do zgromadzenia materiału badawczego posłużono się otwartym wywiadem dziennikarskim, gdyż jest on wrażliwą i skuteczną metodą dostrzeżenia przeżyć innych osób (Kvale, 2004, s. 79). Zastosowanie wywiadów

\footnotetext{
* Statystyki Centralnego Zarządu Służby Więziennej, dostępne na: http://sw.gov. pl/pl/o-sluzbie-wieziennej/statystyka/statystyka-roczna/ (dostęp: 20.03.2015).
} 
dało badanym kobietom możliwość opisania sposobów spędzania czasu wolnego z własnej perspektywy. Sytuacja społeczna skazanych kobiet stanowiła istotny element kontekstu prowadzonego wywiadu (Kvale, 2004, s. 274).

W fazie wstępnej wywiadu poproszono, aby badane kobiety opowiedziały jak spędzają czas wolny w zakładzie karnym. Pytanie to miało za zadanie zainicjować rozmowę. Następnie w dalszym etapie wywiadu skazane pytane były o to, jakie mają dla nich znaczenie poszczególne formy spędzania czasu wolnego. Główne kwestie i interpretacje były rozwijane w zależności od odpowiedzi badanych osób na pytania.

Postępowanie badawcze przyjęło charakter analizy znaczenia treści wypowiedzi badanych w taki sposób, aby doprowadzić do utworzenia jednorodnych tematycznie kondensacji sensu.

Celem analizy zgromadzonego materiału badawczego był opis czasu wolnego w doświadczeniach osób skazanych, a nie przyporządkowanie poszczególnych wypowiedzi do określonego typu form spędzania wolnego, jakie widnieją w literaturze naukowej. Uzasadnienie dla takiego postępowania odnajdujemy w pracach między innymi T. Bauman (2013), D. Urbaniak-Zając (2009) oraz K. Rubachy (2008). Gdyby odnieść się do wskazówek ostatniego autora, to podjęte badania zmierzałyby do ujawnienia rezultatów analizy semantycznej, której podstawą jest odkrywanie jawnej warstwy otwartej wypowiedzi i jej strukturyzacja (w nawiązaniu do sposobów spędzania wolnego czasu), a następnie poszukiwanie intencji badanych na drodze interpretacji badacza - co w tym projekcie oznacza pokazanie znaczenia, jakie kryją się za pogłębionymi odpowiedziami w odniesieniu do potencjału resocjalizacyjnego podejmowanych przez badane kobiety aktywności*

Wywiad przeprowadzony został z 21 kobietami skazanymi na karę pozbawienia wolności w zakładzie karnym o typie półotwartym, z których 17 kobiet było w przedziale wiekowym między 27 a 50 lat i 4 skazane po 50 roku życia. Badane kobiety odbywały karę pozbawienia wolności w systemie programowego oddziaływania, tj. uczestniczyły w oddziaływaniach resocjalizacyjnych. Wychowawczyni zakładu karnego poinformowała kobiety pozostające na oddziale o możliwości wzięcia udziału w badaniach na temat ich czasu wolnego. Badania odbywały się w świetlicy zakładu karnego. Niektóre kobiety wzięły udział pod wpływem namowy swoich koleżanek uprzednio uczestniczących w badaniach, a inne zachęcone zostały przez wychowawczynię.

* Zaadoptowałem procedurę opisaną przez Rubachę K. (2008), Metodologia badań nad edukacja, rozdział VI, Warszawa. 
Oto wyróżnione przez mnie kategorie oddające znaczenie czasu wolnego w wypowiedziach skazanych kobiet.

\section{Czas wolny w wypowiedziach skazanych kobiet}

\section{(A) Praca jako podstawowy wymiar opisu czasu wolnego}

Czas wolny zazwyczaj interpretuje się jako czas wolny od pracy. Jednak współcześnie obserwujemy łączenie, wzajemne przenikanie się czasu pracy i wypoczynku (Nawojczyk, 2011). Dla niektórych skazanych kobiet podstawową formą zagospodarowania własnego czasu wolnego jest podjęcie pracy. Praca skazanych w zakładzie karnym może być odpłatna i nieodpłatna. W momencie, kiedy Polska ratyfikowała Europejską Konwencję Praw Człowieka mówiącą w artykule $4^{*}$, że wolności od niewolnictwa i przymusowej pracy pod żadnym względem nie można ograniczać, nakaz do pracy skazanego został zastąpiony skierowaniem do pracy.

Na przestrzeni wieków praca spełniała różne role w procesie odbywania kary pozbawienia wolności. Role te ewoluowały począwszy od zupełnego zakazu pracy, poprzez pracę o charakterze punitywnym, nakaz pracy, pracy jako środka resocjalizacyjnego, aż do pracy jako nagrody dla osoby skazanej. Współcześnie możliwość pracy podczas odbywania kary pozbawienia wolności jest pewnego rodzaju przywilejem dla skazanych. Jedna z rozmówczyń powiedziała: „Ja to od początku jak tu jestem, to pracuję i dzięki temu jakoś czas płynie". Wydaje się, że wynagrodzenie, jakie otrzymuje ta skazana ma mniejsze znaczenie w stosunku do korzyści wynikających z pracy jako środka pozwalającego zagospodarować czas wolny. Skazana w rozmowie stwierdziła: „To, co dają, to biorę”.

Skazana jest usatysfakcjonowana samym faktem, że może wykonywać tę pracę. Zapewne fakt izolacji więziennej zmienia sposób wartościowania i poznawczego interpretowania przez skazane własnego czasu wolnego. Inna osadzona na temat pracy powiedziała: „Ja pracuję jako krawcowa, bo skończyłam zawodówkę jako krawcowa i teraz robię w takiej firmie prywatnej jakiejś. W sumie to dobrze, bo jest się czym zająć. Bo ja to pracuję od 7:00 do 15:00 pięć dni w tygodniu. Czyli w sumie to tak normalnie, jak inni pracują".

* Europejska Konwencja Praw Człowieka i Podstawowych Wolności. Biuletyn Informacji Publicznej, dostępna na: http://bip.ms.gov.pl/pl/prawa-czlowieka/europejski-trybunal-praw-czlowieka/tekst-europejskiej-konwencji-praw-czlowieka-i-podstawowych-wolnosci-wraz-z-protokolami-dodatkowymi/ (dostęp: 02.04.2015). 
Jak wynika z wypowiedzi badanych, możliwość pracy stanowi dla nich przywilej łagodzący dolegliwości wynikające z nadmiernej ilości czasu wolnego. To, co na wolności może być przywilejem, np. posiadanie czasu wolnego, to w warunkach izolacji penitencjarnej może stanowić źródło problemów osobistych. $Z$ tego powodu na szczególną uwagę zasługuje analiza psychologiczna czasu wolnego posługująca się kategorią przeżywania szczęścia. Według Truszkowskiej (2012) czas wolny może być utożsamiany ze szczęściem, które w pewnych warunkach można osiągnąć także w pracy. Praca wiąże się z aktywnością. Daje ona możliwość samorealizacji i kreatywnego działania. Nie wszystkie osadzone kobiety realizują pracę odpłatną. Niektóre z nich wykonują prace nieodpłatne, lecz o charakterze instytucjonalnym, tj. zorganizowanym przez jednostkę penitencjarną. Ponadto można dostrzec podejmowanie przez skazane prac o charakterze nieformalnym, pozostających poza udziałem administracji zakładu karnego. Skazane wykonując niektóre czynności otrzymują w zamian jakieś dobra materialne.

Jedna ze skazanych kobiet podczas swojego czasu wolnego wykonuje czynności związane ze swoją pracą zawodową, jej wypowiedź: „Lubię czesać koleżanki, bo ja z zawodu fryzjerką jestem. Jak nie mam co robić, to je jakoś ładnie uczeszę".

Inna skazana pozyskuje dobra materialne robiąc papierosy, o czym mówi: „Tak naprawdę to siedzę i robię papierosy, bo to nie każdy tu umie zrobić papierosy, to ja na tym trochę zarobić mogę. Się wymienić znaczy na kawę albo coś słodkiego".

Inne stwierdziły: „Ja lubię przebywać na świeżym powietrzu. Najbardziej to się interesuję ogrodnictwem. Lubię grzebać się w ziemi mimo że większość tego nie lubi. Jak się patrzy jak to wszystko rośnie, to jest takie miłe uczucie w środku”, „Ja to mieszkam normalnie na wsi, to jestem przyzwyczajona, że się samemu wszystko w ogródku ma. Jak byłam na wolności, to już miałam czasami tego dość, ale teraz jak mam ograniczoną możliwość, to mi to sprawia frajdę jak małemu dzieciakowi”. Rozwijanie zainteresowań tych dwóch osadzonych jest możliwe, ponieważ obok bloku, w którym odbywają wyrok, znajduje się mały ogródek, z którego mogą korzystać w okresie wiosenno-letnim. Same sadzą tam warzywa i kwiaty, a następnie pielęgnują je. Warto podkreślić pojawiający się w wielu wypowiedziach kobiet wątek wskazujący na to, że pewne czynności, które na wolności były dla nich uciążliwe, w zakładzie karnym są źródłem przyjemności. Kobiety realizujące swoje hobby w postaci prac ogrodowych, są to osoby po pięćdziesiątym roku życia. Jedna $\mathrm{z}$ nich mieszka w dużym mieście, a druga na wsi. Jak jedna z nich stwierdziła, „Ja to $\mathrm{z}$ taką jedną panią ode mnie $\mathrm{z}$ bloku zajmujemy się tym 
ogródkiem”, „Mam tu taką znajomą, która też się tym interesuje”. Obie kobiety połączyło wspólne zainteresowanie ogrodnictwem. Zakład karny wypożycza tym osadzonym narzędzia ogrodnicze. Skazane mają zagospodarowany czas, dzięki czemu nie nudzą się, a przy okazji korzystają później z plonów, które same wyhodowały.

W czasach starożytnych czas wolny miał szczególną rangę i był oznaką prestiżu. Ilość i sposób jego spędzania w dużej mierze zależał od dobrego urodzenia, a później od odpowiedniego przygotowania (Truszkowska-Wojtkowiak, 2012). Dzisiaj dla wielu ludzi źródłem prestiżu jest praca, która niejednokrotnie jest jedynym punktem odniesienia i źródłem tożsamości. W sytuacji, kiedy chcemy poznać człowieka, często pytamy, gdzie pracuje. Praca skazanych stanowi jedną z istotnych metod resocjalizacji skazanych. Już w XVIII w. pojawiły się zakłady penitencjarne, których naczelnym hasłem było „odrodzenie moralne przez pracę” (Rabinowicz, 1933, s. 29). W zakładach tych uważano, że jedynie praca może przyczynić się do moralnej poprawy przestępcy. Praca jest istotna dla higieny psychicznej skazanych, dla ich sytuacji materialnej, a także dla sytuacji ich rodzin, którą mogą wspierać finansowo. Dodatkowo praca wypełnia skazanym czas, czują się potrzebni oraz mają możliwość nauczenia się nowych umiejętności. Uzyskane wypowiedzi skazanych pokazują, że są one zainteresowane podejmowaniem zatrudnienia. Ważne jest, aby u skazanych wykształciło się przekonanie, że to właśnie praca, a nie przestępczość jest sposobem na życie.

\section{(B)Uczenie się i uzupetnianie edukacji jako formy spędzania czasu wolnego}

W polskim systemie penitencjarnym skazani obejmowani są nauczaniem w szkołach podstawowych, gimnazjalnych, zasadniczych szkołach zawodowych, technikach zawodowych, liceach ogólnokształcących, szkołach policealnych i kursach zawodowych.

Jedna z kobiet, które udzielały wywiadów powiedziała: „Ja to w sumie mam co tu robić, bo ja to do szkoły chodzę. Znaczy się jestem teraz w pierwszej klasie zawodówki. Na krawca się uczę, bo może później jakąś robotę znajdę. No ale to dopiero jak stąd wyjdę". Nauka jest jednym z zasadniczych środków resocjalizacji. Jak wynika z powyższej wypowiedzi, część skazanych kobiet wykorzystuje czas wolny na przygotowanie się do pracy zawodowej na wolności. Dodatkowo możliwość realizacji nauki stanowi istotny element organizacji czasu wolnego przez skazane. Osadzona w chwili rozmowy miała 25 lat. Widziała ona możliwość zdobycia wykształcenia podczas odbywania kary pozbawienia wolności, które może ułatwić jej podjęcie pracy po opuszczeniu zakładu karnego. Jak sama zauważyła, jest to dla niej również sposób 
na zagospodarowanie czasu, który posiada: „Bo ja mam lekcje codziennie od 7:30 do 12:30 i w sumie jak przyjdę, to też coś tam muszę zrobić, że niby takie zadanie domowe. Ja już jestem za stara na takie zadania, ale jak mi się nie chciało wcześniej uczyć, to teraz taka stara, a w szkole siedzę, ale to dobrze, bo chociaż coś z tego więzienia będę miała”.

Osadzona dostrzega wymierne korzyści z podjętej edukacji, co skłania ją do podwyższania swoich kwalifikacji, które będą przydatne przy poszukiwaniu i utrzymaniu zatrudnienia po opuszczeniu jednostki penitencjarnej.

Wypowiedź badanej adekwatnie nawiązuje do wyników z badań uzyskanych przez Kanona-Kol oraz Szczepaniaka (1998), którzy analizowali motywację skazanych do podejmowania edukacji szkolnej podczas odbywania kary pozbawienia wolności. Według przeprowadzonego przez nich badania skazani w $29 \%$ przypadków deklarują, iż warto się uczyć, bo pozwala to „urządzić się” na wolności, w $28 \%$ przypadków podają, że o wartości człowieka bardziej świadczy wiedza niż spryt, $24 \%$ respondentów uważa, że na naukę nigdy nie jest za późno.

W zakładach karnych organizowane są różnego rodzaju kursy i szkolenia pozwalające skazanym na pozyskiwanie wiedzy. Osadzeni uważają, że wiedza ta może być przydatna po opuszczeniu przez nich zakładu karnego. Przykładowe wypowiedzi osadzonych na ten temat: „Taki był no kurs paznokcia. Byłam na nim. Nawet ciekawe to było, nawet mi tam dobrze szło przy tych paznokciach. Tylko w sumie co, przecież jak stąd wyjdę, to nie będę robiła paznokci. Lepiej to by się przydał jakiś kurs na tych no komputerach, bo to w sumie to teraz takie potrzebne jest, a ja już taka starsza jestem i w sumie to nic na nich nie umiem zrobić”, ,Jak mnie jeszcze tu nie było to dziewczyny mówiły, że był taki kurs co się paznokcie robiło. To może mogliby go powtórzyć, bo to taki ciekawy i wtedy się ładnie wygląda”, „Ja byłam na takim kursie. Jak on się nazywał? No teraz nie pamiętam, ale chodziło o to, jak znaleźć pracę po tym, jak stąd wyjdziemy. W sumie to chyba nawet może się przydać”, „Na tym kursie o pracy to my miałyśmy napisać taki jakby życiorys i taki list, dlaczego chcemy akurat tu pracować. To się chyba przyda nie".

Brak wykształcenia oraz brak umiejętności społecznych i zawodowych przydatnych na współczesnym rynku pracy powoduje, że wiele z tych osób po opuszczeniu zakładu karnego jest zagrożonych powrotem do przestępczości. Niestety, jak twierdzą osadzone, tylko osoby przebywające dłużej w zakładzie karnym biorą udział w szkoleniach. W szkoleniach najczęściej uczestniczyły kobiety pozostające w zakładzie już od ponad roku. Fakt ten można tłumaczyć tym, że albo nie było tych szkoleń wcześniej, albo na tego typu szkolenia kierowane są osoby pozostające dłużej w zakładzie karnym 
lub też dostępna jest niewielka liczba miejsc. Również osoby odbywające krótkie kary pozbawienia wolności mogą nie wymagać przekwalifikowywania, gdyż krótkoterminowa izolacja nie musi organizować ich zawodowego funkcjonowania po opuszczeniu zakładu.

\section{(C)Zajęcia kulturalno-oświatowe jako sposób spędzania wolnego czasu}

Działalność twórcza i kulturowa stanowią nie tylko podstawę rozwoju formacji społecznych, ale także sposób na życie. Jest to pewnego rodzaju autoteliczne spędzanie czasu. Wiąże się ono z przeżywaniem czasu wolnego jako stanu umysłu (Truszkowska-Wojtkowiak, 2012).

W każdej jednostce penitencjarnej prowadzona jest biblioteka i szereg działań kulturalno-oświatowych oraz sportowych. Działają grupy teatralne, zespoły muzyczne, pracownie plastyczne i rzemiosła artystycznego. Organizuje się doroczne przeglądy sztuki więziennej, w których mogą uczestniczyć skazani z jednostek w kraju (Jarzębowska-Baziak, 1972). Wszystkie rozmówczynie wspomniały o działaniach kulturowo-oświatowych prowadzonych przez zakład karny: „Są jakieś tam koncerty i pogadanki, ale ja na nie nie chodzę, bo jak wracam z pracy, to mi się nie chce”, „Ja to w sumie bym poszła na takie coś, ale jestem tu krótko i mnie nie wezmą”, „Czasami to jakiś teatr mamy, a i pamiętam, jak kiedyś jakiś kabaret przyjechał, ale ja na tym nie byłam, tylko inna taka jedna była, ale ona to tu już długo jest, to na takie coś może chodzić, bo ją częściej biorą", „W sumie to tylko koncert był, nawet na nim byłam, ale nie pamiętam, kto śpiewał. Nawet fajnie było", „Był jakiś koncert, ale to już dawno”. Z wypowiedzi osadzonych wywnioskować można, że zakład karny stara się organizować wolny czas osadzonych tak, aby uwzględniał on również zajęcia kulturalno-oświatowe. W wypowiedziach badanych pojawił się wątek ograniczania dostępu do niektórych wydarzeń kulturalnych organizowanych przez zakład karny. Można dostrzec, że jednym z kryteriów doboru jest czas pobytu w izolacji penitencjarnej. Osoby, których czas pobytu w zakładzie był dłuższy częściej spotykają się z szerszą ofertą kulturalno-oświatową. Zapewne wychowawcy penitencjarni mogą chcieć nieco urozmaicić dotychczasowe oddziaływania kulturalno-oświatowe oraz w pewnym stopniu złagodzić skazanym dolegliwości długotrwałego pobytu. Zajęcia kulturalno-oświatowe organizowane przez zakład karny muszą być należycie przemyślane, aby były dostosowane do potrzeb skazanych, ich możliwości psychofizycznych, realizowały cele resocjalizacyjne i jednocześnie zapewniały wszystkim bezpieczeństwo w jednostce penitencjarnej. 
Niektóre kobiety starają się przełamać wystandaryzowany i surowy wystrój swoich cel: „Jak mi się nudzi, to robie coś, żeby wystrój naszej celi był ładniejszy, bo one za ładne to nie są”, „Ja to w sumie sobie odpoczywam”, „Ja jestem KO. To taka kultura i oświata trochę, to jak mam czas, to przygotowuję jakieś krzyżówki albo dyktanda, ale to jak mi się chce, bo tu to nawet materiałów nie mam żadnych. Nawet kartek czy pisaków nie ma”. Czasami bywają organizowane zajęcia w świetlicy zakładu karnego. Jednak wiele osób nie jest zainteresowana uczestniczeniem w tych spotkaniach: „Większość osób nie chce przychodzić. Wolą telewizję oglądać".

Skazane starają się w różny sposób zorganizować sobie czas wolny urozmaicając go w możliwie jak najlepszym stopniu. W warunkach więziennych działalność kulturowo-oświatowa jest istotnym środkiem estetycznego i moralnego kształtowania człowieka. Ma to szczególne znaczenie w odniesieniu do tych skazanych, którzy w związku z przejawianiem antyspołecznych cech osobowości mają trudności w ustaleniu granic między dobrem a złem i w wartościowaniu otaczających ich zjawisk.

Bardzo często uczestnictwo w kulturze osadzonych kobiet, podobnie jak i mężczyzn, ogranicza się do codziennego kontaktu z telewizją. Inne aktywności, np. czytanie książek i prasy, są znacznie rzadsze. W przypadku czytelnictwa rozmówczynie stwierdziły: „Ja dużo czytam, interesuję się wieloma rzeczami. Lubię przeczytać dobrą książkę. To mnie relaksuje”, „Czytam dość dużo, bo w sumie to tu nie ma nic innego ciekawego do robienia, a te wszystkie seriale to takie głupie są, że szkoda na to tracić czasu, ale młode, to tego nie rozumieją". Należy wspomnieć, iż obie wypowiedzi padły z ust osób, które ukończyły 50. rok życia i mają co najmniej średnie wykształcenie.

Zauważyć można natomiast dość częste czytanie gazet plotkarskich, takich jak: „Życie na Gorąco”, „Fakt”, „Super Express”. Świadczą o tym wypowiedzi typu: „Ja to lubię takie tam ploty czytać”, „W sumie jak już czytam, to raczej o tych, jak to się teraz mówi, celebrytach, bo oni to takie ciekawe życie mają", „Ja jak już mam coś czytać, to wolę o tych gwiazdach czytać niż o tych politykach”, „Ja młoda jeszcze jestem, to nie czytam takich poważnych rzeczy, ja wolę hmm... brukowce, bo tam ciekawe historie są i pośmiać się można czasami”.

Skazane kobiety czytają gazety, które pozwalają im oderwać się od monotonii dnia w zakładzie karnym. Czytają o celebrytach, z których stylem mogą się identyfikować lub go potępiać. Osadzone interesują się losami sławnych osób. Dzięki temu poprawia się ich samopoczucie, doświadczają przyjemnych odczuć uwalniając się od swojej „szarej rzeczywistości”. 


\section{(D) Gry jako forma spędzania wolnego czasu}

Część osadzonych gra w karty, kości i warcaby: „My to z koleżankami z celi gramy w makao i wojnę i czasami w tysiąca, bo do innych gier to zasad nie znamy, a z tego co słyszałam, to poker trudny jest, to po co się denerwować, że komuś nie idzie”, „Czasami wieczorem jak siedzimy to zagramy sobie w karty. W sumie to sporo gramy w te karty, ale raczej w takie łatwe jakieś, albo w kości gramy, bo to łatwe jest, tylko my nie liczymy punktów, bo w sumie nie wiemy, jakie są zasady ich liczenia. Tylko kto pierwszy zrobi te wszystkie tam fule i generały, to wygrywa”, „Mamy na celi warcaby i w sumie szachy też, ale w szachy to nie umiemy grać, to chociaż w warcaby tak dla zabicia czasu".

Sytuacje w grach są nieprzewidywalne, ale w dużym stopniu mogą być rozwiązywane w sposób twórczy. Gry zawierają w sobie element rywalizacji, a także spełniają wiele ról przypisanych zabawom w życiu dorosłego człowieka. Gra uczy także przegrywania, bowiem często zwycięzca jest tylko jeden i trzeba umieć mu pogratulować sukcesu oraz docenić korzyści, jakie sami odnieśliśmy w trakcie rywalizacji. $Z$ wypowiedzi skazanych można dostrzec, że korzystają one z dość wąskiego asortymentu gier. Jednocześnie nie znają one zasad popularnych gier planszowych. W związku z tym warto byłoby, aby wychowawcy odpowiedzialni za działalność kulturalno-oświatową podjęli działania edukacyjne mające na celu zapoznanie skazanych z zasadami gier, które mogą podtrzymywać i rozwijać procesy poznawcze.

\section{(E) Sport jako aktywność pożądana i rezultat potrzeby rywalizacji}

W codziennym życiu ważną rolę odgrywa aktywność fizyczna. Jak wiadomo, sport to nie tylko zdrowie fizyczne, ale także psychiczne. Mimo istniejących trudności lokalowych, niektóre skazane potrafią samodzielnie zadbać o wysiłek fizyczny: „Ja to się interesuje każdego rodzaju sportem. Tylko, że tu to z tym problem jest, bo cele są ciasne, ale mimo to z koleżankami na celi ćwiczymy aerobik”, „Ja to w sumie to lubię tańczyć, ale to przecież jest jak sport, kurczę nawet kurs tańca można by było tu zrobić. Ale fajnie by było”, „W sumie to my wszystkie na celi ćwiczymy, bo od tego siedzenia, to już tylko tyłek rośnie, a i dzięki temu, to czas jakoś mija”. Jak widać, sportem interesuje się, a nawet regularnie ćwiczy ponad połowa rozmówczyń. Prawdopodobnie jest to efekt tego, iż cztery z nich są z tej samej celi i wszystkie ćwiczą aerobik. Wszystkie zgodnie stwierdziły, że „przydałby się jakiś kurs albo trener, bo mamy tylko książkę". Warto nadmienić, iż wszystkie z osób zainteresowanych zajęciami sportowymi są w przedziale wiekowym od 20-31 lat. Osoby starsze w mniejszym stopniu odczuwają potrzeby ćwiczenia: „Ja mam 56 
lat i w sumie to już po schodach wejść nie mogę. Tylko tyle co tu po korytarzu, ale dla młodych to niech coś zrobią, bo później, to będą tak jak ja”.

Osadzone mają świadomość, że kiedy opuszczą zakład karny, będą musiały być w dobrej kondycji, żeby szukać pracy i móc ją uzyskać: „Teraz to tu dużo tylko siedzi i nic nie robi, a jak się wyjdzie, to trzeba roboty szukać, a to też trzeba mieć zdrowie. A to na pewno nie dostanę pracy w biurze, no chyba że jako sprzątaczka. To jak będę robiła jako, jak to się mówi siła robocza, to zdrowie i siła potrzebne".

Poza chęcią posiadania dobrej kondycji fizycznej głównym motywem do podejmowania aktywności przez skazane jest chęć wspólnego udziału w ćwiczeniach, a także możliwość wyróżnienia się dzięki pewnym przejawom rywalizacji i współzawodnictwa. Skazane twierdzą, że przyjemnie jest wygrywać „bo wiadomo, że każdy lubi być najlepszy. Ja na przykład jestem najlepsza z naszej celi w aerobiku, bo mam rozciągnięte ciało”.

Osadzone podejmują wysiłek fizyczny, w czasie którego szukać mogą harmonii w czynnościach swego ciała: oddechu, tętna czy wreszcie bólu i zmęczenia. Wysiłek treningowy może być równie dobrze przeżyciem autotelicznym, któremu towarzyszy określony stan umysłu, jak i aktem kinestetycznym, u podstaw którego leżą procesy fizjologiczne. Badacze aktywności ruchowej mówią nawet o swego rodzaju samorealizacji ludzi nastawionych na uzyskanie doskonałości fizycznej. Co więcej, wskazują, że jest to najbardziej pierwotna forma samorealizacji (Truszkowska, Wojtkowiak, 1999). Za pośrednictwem ćwiczeń ruchowych osadzone kobiety mają możliwość sprawdzenia siebie oraz przekraczania własnych granic zarówno fizycznych, jak i psychicznych.

\section{(F) Czas wolny jako czas na kontakt z rodzing}

Znaczną część wolnego czasu skazane poświęcają na pisanie listów do domów i rozmowy telefoniczne: „No ja to w sumie większość wolnego czasu listy do córki piszę, bo jestem ciekawa, co tam u niej słychać. Tak naprawdę to codziennie piszę listy. Czasami to ich nawet nie wysyłam, ale jakoś tak mi lżej, jak coś napiszę”, „Ja krótko przedtem, jak tu trafiłam, to za mąż wyszłam i do męża piszę, że u mnie wszystko dobrze, żeby się tam o mnie nie martwił, bo po co ma się martwić”, „A co mam robić, głównie to listy piszę".

Bardzo istotne dla osadzonych są również rozmowy telefoniczne: „Ja to dużo czasu myślę, jeszcze zanim zadzwonię, co mam powiedzieć. To najpierw sobie wszystko zapiszę albo przemyślę i wtedy to dzwonię, bo inaczej to dużo rzeczy bym zapomniała zapytać albo powiedzieć". Zauważyć nale- 
ży, jak ważny jest dla skazanych kontakt z rodziną i jak dużo czasu wolnego, który posiadają, spędzają właśnie na kontakcie z nią oraz na myśleniu o niej.

\section{Podsumowanie. Walory edukacyjne aktywności skazanych a bycie odpowiedzialnym dorosłym}

Organizacja czasu wolnego jest bardzo istotna, szczególnie jeśli dotyczy ona osób, które mają tego czasu bardzo dużo oraz posiadają ograniczone możliwości. Właśnie taką grupą są osoby odbywające karę pozbawienia wolności w zakładzie karnym. Wszystkie osadzone, z którymi przeprowadzone zostały wywiady stwierdziły, że „odgórne organizowanie różnych form spędzania czasu wolnego ma dla nich istotne znaczenie, "wszystkie te zajęcia mają sens".

Czas wolny, jakim dysponują kobiety w jednostkach penitencjarnych, powinien wspierać przygotowanie ich do życia w rodzinie i społeczeństwie, do współdziałania w pracy zawodowej oraz działalności społecznej. Kształtowanie odpowiedniego wzorca spędzania czasu wolnego przez skazane kobiety powinno być wspomagane przez personel penitencjarny. Nie oznacza to, że resocjalizacja ma mieć miejsce wyłącznie w sytuacji bezpośredniego kontaktu podopiecznych z wychowawcą.

Umożliwienie kobietom skazanym na karę pozbawienia wolności spędzania czasu wolnego w kontekście resocjalizacyjnym nakłada na personel penitencjarny szereg zadań. Wymaga od niego dobrego przygotowania do podejmowania kolejnych czynności, zapewnienia warunków do ich wykonania, zagwarantowania środków, koncentrowania sił, utrzymywania ładu i dyscypliny, harmonijnego układu czasu czynności obowiązkowych i rekreacyjno-wypoczynkowych. Właściwe wykorzystanie czasu wolnego przez skazane kobiety może stanowić cenne momenty w kształtowaniu ich osobowości. Z punktu widzenia resocjalizacji skazanych istotne jest wdrażanie ich do prawidłowej organizacji czasu wolnego oraz dokonywanie analizy jego racjonalności. Organizacja i budżet czasu wolnego powinna uwzględniać zarówno aspekty zdrowotne, ale także odnowę psychiczną. Dla wielu kobiet skazanych na karę pozbawienia wolności nauka racjonalnego i aktywnego wykorzystania czasu wolnego powinna być traktowana jako kształtowanie nawyków przygotowujących do samodzielnego funkcjonowania w społeczeństwie po opuszczeniu zakładu karnego. Uspołecznienie czasu wolnego $\mathrm{w}$ jednostkach penitencjarnych powinno polegać przede wszystkim na 
kształtowaniu jego kultury poprzez wypełnianie go wartościową treścią, która wpływa na wzbogacenie osobowości człowieka.

\section{Bibliografia}

Europejska Konwencja Praw Człowieka i Podstawowych Wolności. Ratyfikowana przez Polskę 19 marca 1993, Biuletyn Informacji Publicznej. Data wydania 1 czerwca 2010, dostępna na: http://bip.ms.gov.pl/pl/prawa-czlowieka/europejski-trybunal-praw-czlowieka/tekst-europejskiej-konwencji-praw-czlowieka-i-podstawowych-wolnosci-wraz-z-protokolami-dodatkowymi/ (dostęp: 02.04.2015).

Bauman T. (2013), Kompetencje badawcze a świadomość metodologiczna, [w:] T. Bauman (red.), Praktyka badań pedagogicznych, Oficyna Wydawnicza „Impuls”, Kraków.

Konon-Kol M., Szczepaniak P., W poszukiwaniu modelu edukacji resocjalizacyjnej. Przegląd doświadczeń w USA i w Polsce, "Przegląd Więziennictwa Polskiego" 1998, s. 20-21,16-22.

Grochociński M. (1980), Rodzina a czas wolny, Krajowa Agencja Wydawnicza, Gdańsk.

Grabowiec A. (2011), Samoocena dzieci krzywdzonych w rodzinie, Wydawnictwo UMCS, Lublin.

Jarzębowska-Baziak B. (1972), Praca wychowawcza w zakładzie karnym dla młodocianych, Wydawnictwo Prawnicze, Warszawa.

Jurgiel-Aleksander A. (2013), Doświadczenia edukacyjne w perspektywie andragogicznej. Studium biograficzno-fenomenograficzne, Wydawnictwo Uniwersytetu Gdańskiego, Gdańsk.

Kubinowski D. (2010), Jakościowe badania pedagogiczne. Filozofia, metodyka, ewaluacja, Wydawnictwo UMCS, Lublin.

Kvale S. (2004), Interview. Wprowadzenie do jakościowego wywiadu badawczego, Trans Humana, Białystok.

Mroczkowska D. (2011), Czas wolny. Refleksje, dylematy, perspektywy, Difin, Warszawa.

Nawojczyk M. (2011), Czas wolny - pochodna czy determinanta pozycji społecznej, [w:] D. Mroczkowska (red.), Czas wolny. Refleksje, dylematy, perspektywy, Diffin, Warszawa, s. 12-15.

Parol R. (2009), Modele czasu wolnego i ich znaczenie w kształtowaniu prozdrowotnego stylu życia w ujęciu pedagogiki resocjalizacyjnej, [w:] W. Muszyński (red.), Małe tęsknoty: Style życia w czasie wolnym we współczesnym społeczeństwie, Wydawnictwo Adam Marszałek, Toruń, s. 394-403.

Pięta J. (2004), Pedagogika czasu wolnego, Wydawnictwo Wyższej Szkoły Ekonomicznej, Warszawa. 


\section{2 | Robert Opora}

Przecławski K. (1993), Czas wolny, [w:] W. Pomykało (red.), Encyklopedia pedagogiczna, Wydawnictwo Fundacja „Innowacja”, Warszawa.

Pustkowiak L., Kontakty skazanych ze światem zewnętrznym, „Opieka. Wychowanie. Terapia" 2005, 1/2, s. 46-56.

Rabinowicz L. (1933), Podstawy nauki o więziennictwie, Wydawnictwo Gebethner i Wolff, Warszawa.

Rejzner A. (2002), Stan i kierunki badań penitencjarnej kultury fizycznej, [w:] A. Rejzner, (red.), Penitencjarna Kultura fizyczna, Wydawnictwo Akademickie „Żak”, Warszawa, s. 69-86.

Rubacha K. (2008), Metodologia badań nad edukacja, Wydawnictwa Akademickie i Profesjonalne, Warszawa.

Schopenhauer A. (1970), Aforyzmy o mądrości życia, Czytelnik, Warszawa.

Statystyki Centralnego Zarządu Służby Więziennej, dostępne na: http://sw.gov.pl/ /pl/o-sluzbie-wieziennej/statystyka/statystyka-roczna/ (dostęp: 20.03.2015).

Tatarkiewicz W. (1986), O filozofii i sztuce, Państwowe Wydawnictwo Naukowe, Warszawa.

Truszkowska M., Wojtkowiak J. (1999), Edukacja wczesnoszkolna a problem rozwoju kreatywnego w świetle teorii Artura Koestlera i Howarda Gardnera. Uwagi metodologiczne, [w:] R. Grzybowski, M. Krasnopolski, Z. Pawluczuk (red.), Humanistyczny wymiar edukacji nauczycieli wychowania fizycznego, Wydawnictwo AWF, Gdańsk, s. 241-248.

Truszkowska-Wojtkowiak M. (2012), Fenomen czasu wolnego, Harmonia, Gdańsk.

Urbaniak-Zając D. (2009), W poszukiwaniu kryteriów oceny badań jakościowych, [w:] D. Kubinowski, M. Nowak (red.), Metodologia pedagogiki zorientowana humanistycznie, Oficyna Wydawnicza „Impuls”, Kraków. 